\title{
Konsep Pendidikan Islam yang Ideal: Upaya Pembentukan Keperibadian Muslim
}

\author{
SHOLEH \\ Fakultas Agama Islam (FAI) Universitas Islam Riau (UIR) Pekanbaru \\ Jl. Kaharuddin Nasution, No. 113, Perhentian Marpoyan Pekanbaru 28284
}

\begin{abstract}
Abstrak: Pendidikan merupakan proses pembentukan kepribadian yang merupakan hasil dari proses pembelajaran. Melalui lembagalembaga pendidikan diharapkan tidak hanya mampu menghadapi masyarakat teknologi masa depan yang makin teknologis tetapi juga pendidikan berpengaruh terhadap proses pembentukan dan pengembangan sikap dan prilaku manusia. Pendidikan yang ideal diyakini dapat melayani pertumbuhan manusia dalam semua aspek, baik aspek spiritual, intelektual, imajinasi, maupun aspek ilmiah. Dengan demikian proses pendidikan ini sebaiknya mendorong aspek tersebut ke arah keutamaan serta pencapaian kesempurnaan hidup melalui pembentukan karakter kepribadian. Melalui pembentukan karakter kepribadian muslim diharapkan dapat melahirkan individuindividu yang baik, bermoral, berkualitas sehingga bermanfaat bagi dirinya, keluarganya, masyarakatnya, bangsanya serta umat manusia umumnya.
\end{abstract}

Kata kunci: Pendidikan islam, karakter kepribadian muslim

\section{PENDAHULUAN}

Hubungan antara pendidikan dengan masyarakat erat sekali, maka dalam proses pengembangannya saling mempengaruhi. Mesin pendidikan yang kita namakan sekolah dalam proses pengembangannya tidak terlepas dari mesin sosial. Mesin sosial menggerakkan segenap komponen kehidupan manusia, terdiri dari sektorsektor sosial, politik dan agama. Masingmasing sector ini bergerak dan berkembang saling mempengaruhi menuju kearah tujuan social yang telah ditetapkan.
Bilamana kesemuanya berada di dalam pola yang harmonis dan serasi, maka masyarakat pun bergerak dan bergerak secara harmonis. Akan tetapi, jika salah satu atau beberapa sektornya mengalami ketidak harmonisan, maka sektor-sektor lainnya akan terpengaruh. Dari sinilah awal dari terjadinya krisis kehidupan masyarakat yang pada gilirannya melanda sekolah, bahkan sekolah ditekan dan dibebani tugas untuk memberikan konsep-konsep penyelesaiannya.

Fenomena sosial yang telah diteliti oleh para ahli perencanaan kebijakan 
pendidikan misalnya, menunjukkan bukti bahwa setiap tahap kemajuan ilmu dan teknologi canggih, selalu membawa perubahan sosial yang sepadan atau bahkan lebih besar dari pada perkiraan atau peramalan mereka. Dampak positif dan negatifnya terhadap kehidupan manusia kadang-kadang tidak dapat lagi dikontrol atau diarahkan oleh lembagalembaga sosial dan kultural atau moral yang sengaja dibangun oleh masyarakat seperti sekolah.

Dalam arena kehidupan masyarakat yang dipetakan oleh para ahli sebagai suatu kesuraman dan kekusutan karena berbagai dampak iptek yang mengerosi nilai-nilai seluruh bidang-bidang kehidupan, maka apa dan bagaimana lembaga-lembaga pendidikan Islam pada khususnya dan lembaga pendidikan pada umumnya harus berperan yang paling baik? Inilah pertanyaan yang layak diajukan kepada umat Islam yang kedudukannya sebagai umat di tengah-tengah masyarakat.

Pendidikan baru dari berbagai disiplin keilmuan yang dilakukan secara integralistik amat diperlukan, untuk mendorong pendidikan Islam yang mampu menghadapi masyarakat teknologi masa depan yang makin teknologis.

Self kritik terhadap kondisi pendidikan islam masa kini antara lain di lontarkan oleh Prof. Dr. Fadhil alDjamaly yang menyatakan sebagai berikut :

"Dunia Islam yang sedang dilanda kemunduran dan keterbelakangan, kemiskinan, serta ketinggalan iptek, tidak dapat diatasi dengan mengimpor system pendidikan barat yang tidak sesuai dengan aspirasi bangsa-bangsa Islam.Sistem dari luar itu hanya lebih mementingkan kulit daripada isi dan mutiara: juga hanya lebih mementingkan kualitas daripada kuantitas: tidak pula sesuai dengan makna dan cita-cita anak didik dalam proses pengembangan kemampuan pembawaanya.Oleh karena itu, system tersebut tidak dapat memecahkan permasalahan Negara yang sedang membangun bahkan bahkan seringkali menimbulkan permasalahan-permasalahan baru bagi masyarakat yang menerapkan system itu."

Dr. Fadhil al-Djamaly menghimbau agar umat Islam menciptakan pendidikan yang didasari keimanan kepada Allah, karena hanya dengannya adalah merupakan suatu dasar yang benar untuk menuntut ilmu.

Pendidikan islam yang diharapkan mencapai sukses menurut seorang pemikir pembaharuan umat Islam, Syekh Sayyid Qutb, (This Religion of Islam ) bila mengacu kepada: (1) Sistem kehidupan yang mengartikulasikan dan mengaktualisasikan sifat dasar manusia (Human Nature), dimana Islam di turunkan oleh Allah justru untuk mengembalikan sifat dasar manusia itu; dan (2) Sistem kehidupan Islam menanamkan cita-cita untuk melepaskan diri dari segala bentuk penindasan oleh orang-orang yang kuat terhadap orang yang lemah, membebaskan manusia dari kebodohan dan kemiskinan serta keterbelakangan.

Imbauan tersebut meskipun bernada pareanilistik dan esensialistik, namun dapat kita resapi maknanya, yaitu bahwa pendidikan Islam adalah pendidikan yang di harapkan oleh umat Islam yang mampu menjadi obor yang menerangi kebingungan dan kegelapan hidup manusia masa kini. Sehingga secara maksimal dapat menjadi benteng moral bagi masyarakat dan teknologi yang pragmatis anti moralitas Illahi yang Absolut.

Diharapkan dengan menyerap nilai-nilai Islam seperti yang muncul dan berkemampuan tinggi pada permulaan risalahnya, kemudian di 
konseptualisasikan kedalam system nilai yang mengacu kepada tuntutan baru, maka validitas pendidikan Islam akan bangkit kembali.

Pendidikan baru dari berbagai disiplin keilmuan yang dilakukan secara integralistik sangat diperlukan untuk mendorong pendidikan islam yang mampu menghadapi masyarakat teknologi masa depan yang makin teknologis.Barangsiapa menguasai iptek, maka ia akan dipertahankan dengan system pendidikannya di masa depan.

Inilah suatu orientasi baru pendidikan Islam kepada masa depan yang serba ditakuti dan dicemaskan oleh para futurologiyang mengeluhkan bahwa "Disorientasi yang memusingkan kepala yang ditimbulakn oleh kedatangan hari esok begitu cepat ", menyebabkan sekolah kedodoran mengejar ketertinggalan.

Beberapa ahli perencanaan kependidikan masa depan telah mengidentifikasikan krisis pendidikan yang bersumber dari krisis orientasi masyarakat masa kini, dapat pula dijadikan wawasan perubahan system pendidikan Islam, yang mencakup fenomena-fenomena antara lain sebagai berikut: (1) Krisis nilai-nilai. Krisis nilai berkaitan dengan masalah sikap menilai sesuatu perbuatan tentang baik dan buruk, pantas dan tidak pantas, benar dan salah, dan hal-hal lain yang menyangkut perilaku etis individual dan sosial. Sikap penilaian yang dahulu diterapkan sebagai "benar, baik, sopan, atau salah, buruk, tak sopan" mengalami perubahan drastis menjadi ditoleransi, sekurang-kurangnya tak diacuhkan orang; (2) Krisis Konsep tentang kesepakatan arti hidup yang baik. Masyarakat mulai mengubah pandangan tentang cara hidup bermasyarakat yang baik dalam bidang ekonomi, politik, kemasyarakatan, dan implikasinya terhadap kehidupan individual. Nilainilai apa yang dijadikan ukuran, menjadi kabur. Sekolah yang menjadikan cermin idealitas masyarakat, risau tentang adanya kekaburan konsep tersebut, sehingga sulit untuk dipantulkan ke dalam program-program kependidikan. Kalau mau mengambil konsep etika Islam, sekolah kita tidak akan mengalami kesulitan dalam melaksanakan tugas dan fungsinya sebagai sarana pembudidayaan manusia; (3) Adanya kesenjangan kredibilitas. Dalam masyarakat manusia saat ini dirasakan adanya erosi kepercayaan di kalangan kelompok penguasa dan penanggung jawab social. Di kalangan orang tua, guru, penegak hukuim dan sebagainya mengalami keguncangan jiwa, mulai diremehkan orang yang semestinya manaati atau mengikuti petuahnya; (4) Beban Institusi sekolah kita terlalu besar melebihi kemampuannya. Sekolah kita dituntut untuk memikul beban tanggungjawab moral dan sosiokultural yang tidak termasuk program instruksional yang didesain, oleh karenanya sekolah tidak siap memikul tanggung jawab tersebut. Sistem birokrasilah yang telah memperberat beban yang yang diluar kemampuan sekolah. Seperti membebani titipantitipan matapelajaran yang bersifat menunjang kebijaksanaan teknis departemental atau sektoral; (5) Kurangnya sikap idealisme dan citra remaja kita tentang peranannya di masa depan bangsa. Sekolah dituntut untuk mengembangkan idealism dan selfimage generasi muda untuk berwawasan masa depan yang realistis. Sehingga mereka mau mempersiapkan diri untuk berperan serta dalam pembangunan bangsanya sesuai dengan keahlian, ketrampilan, dan IPTEK yang amat diperlukan oleh Negara; (6) Kurang sensitif terhadap kelangsungan masa depan. Falsafah hidup yang 
dogmatis dan statis yang tidak mengacu kepada kelangsungan hidup masa depan, tidak lagi dapat diandalkan untuk menjadi landasan sikap sekolah masa kini. Tradisi-tradisi yang membelenggu kebebasan berfikir dan berkreasi anak didik harus dibuang jauh, sehingga sekolah kita akan menjadi institusi kependidikan yang dinamis. Ini mendorong anak didik belajar secara intensif berorientasi kearah masa depan tekno, sosio, dan bio yang realistis, tapi moralistis; (7) Kurangnya relevansi program pendidikan di sekolah dengan kebutuhan pembangunan. Sekolah yang mendukung kepentingan elit nonpopulis, tidak demokratis, tidak berorientasi kea rah kepentingan pembangunan tidak akan dapat mempertahankan eksistensi dalam masyarakat yang sedang membangun; (8) Adanya tendensi dalam pemanfaatan secara naïf kekuatan teknologi canggih. Kenaifan dalam pemanfaatan kekuatan teknologi modern menimbulkan keprihatinan para pecinta lingkungan.Bahkan menimbulkan kerawanan yang dapat menghancurkan kehidupan umat manusia sendiri seperti timbulnya krisis energy, polusi air dan udara dan lain sebagainya: (9) Makin membesarnya kesenjangan antara si kaya dan si miskin. Sekolah yang kita andalkan menjadi tumpuan harapan bagi peningkata kesejahteraan hidup ekonomis, memerlukan dukungan berimbang agar para orang tua dapat menyekolahkan anaknya entah itu dari golongan kaya ataupun miskin.Dalam hal ini sekolah dituntut untuk berlaku adildan demokratis dalam pendidikan; (10) Ledakan pertumbuhan jumlah penduduk. Dilihat dari grafis pertumbuhan, Indonesia termasuk dalam Negara di dunia, Indonesia masuk kedalam golongan Negara dengan tingkat pertumbuhan penduduk yang tinggi. Hal ini menimbulkan dampak semakin membengkaknya jumlah pengangguran. Benarlah teori Malthus yang mengatakan bahwa pertumbuhan ekonomi langsung menurut deret hitung. Sekolah kita terus menerus memproduksi tenaga kerja yang bertarget setiap tahun. Sampai saat ini sekitar 9 juta lebih yang menganggur; (11) Makin bergesernya sikap manusia kea rah pragmatis yang pada gilirannya akan membawa kepada sikap matrealistis dan individualis. Kecenderungan sikap hidup manusia modern saat ini seolah lebih mengedepankan sikap dan pola hidup yang lebih mementingkan dekadensi moral dan kekayaan materi, sehingga mengurangi sikap dan pola hidup sederhana dan beroriesntasi pada nilainilai agama; (12) Makin menyusutnya jumlah ulama tradisional dan kualitasnya. Kecenderungan tersebut sudah tampak didaerah perkotaan dalam era pembangunan negeri saat ini hingga menimbulkan suatu pertanyaan "Hingga berapa besarkah yang harus dipertanggung jawabkan oleh institusi pendidikan dan social yang dapat kita tunaikan."

\section{KONSEP TEORI}

\section{Pengertian Tarbiyah Islamiyah}

Pendidikan Islam tidaklah memadai jika semata-mata dipahami hanya sebatas sebagai "ciri khas" jenis pendidikan yang berlatar keagamaan, namun merupakan suatu upaya atau proses pencarian, pembentukan dan pengembangan sikap dan prilaku untuk mencari, mengembangkan dan memelihara serta menggunakan ilmu dan perangkat teknologi atau keterampilan demi kepentingan manusia sesuai dengan ajaran islam.

Di dalam khazanah Islam ada dua istilah yang dipakai untuk pendidikan 
yaitu tarbiyah dan ta'dib, kedua istilah ini mempunyai perbedaan yang mencolok.

Menurut Naquib al-Atas, tarbiyah secara semantik tidak khusus ditujukan untuk mendidik manusia, tetapi dapat dipakai kepada spesies lain, seperti mineral, tanaman dan hewan. Selain itu tarbiyah berkonotasi material: ia mengandung arti mengasuh, menanggung, memberi makan, mengembangkan, memelihara, membuat, menjadikan bertambah pertumbuhan, membesarkan, memproduksi hasil-hasil yang sudah matang dan menjinakkan. Adapun ta'dib mengacu pada pengertian ('ilm), pengajaran ( $\mathrm{ta}^{\prime} \mathrm{lim}$ ) dan pengasuhan yang baik (tarbiyah). Dari itu katanya ta'dib merupakan istilah yang paling tepat dan cermat untuk menunjukkan pendidikan dalam Islam. Nampaknya Naquib melihat ta'dib sebagai sebuah sistem pendidikan Islam yang didalamnya ada tiga sub sistem, yaitu pengetahuan, pengajaran dan pengasuhan (tarbiyah). Jadi tarbiyah dalam konsep Naquib ini, hanya satu sub sistem dari ta'dib.

Untuk dapat menolak atau menerima konsep Prof. Naquib itu, kita perlu memperhatikan pemakaiannya oleh Al-Qur-an dan penerapannya oleh orang Arab sendiri dalam sejarah peradaban Islam. Ibnu Manzhur mencatat tarbiyah berasal dari akar kata raba - yarbu, rabiya - yarba dan rabba yarubbu. Al-Jauhari menegaskan, kata itu berarti sesuatu yang tumbuh seperti anak-anak, tanaman dan sebagainya. Sedangkan ar Raghib al Ashfahani dalam kitab mufradat menyatakan : "Makna asal ar Rabb adalah At Tarbiyyah yaitu memelihara sesuatu sedikit demi sedikit hingga sempurna ". Dari ketiga kata ini, Pendidikan (tarbiyyah) dapat disimpulkan terdiri atas empat unsur, yaitu: (1) Menjaga dan memelihara fitrah anak menjelang baligh; (2) Mengembangkan seluruh potensi dan kesiapan yang bermacam-macam; (3) Mengarahkan segala fitrah dan potensi ini menuju kebaikan dan kesempurnaan yang layak baginya; dan (4) Proses ini dilaksanakan secara bertahap sebagaimana diisyaratkan oleh ar Raghib dengan "sedikit demi sedikit".

Kemudian kalau kita perhatikan dalam perkembangan sejarah peradaban Islam semenjak masa Nabi sampai masa keemassannya di tengah Bani Al-Abbas, kata tarbiyah tak pernah muncul dalam literatur-literatur pendidikan. Barulah di abad modern kata ini mencuat kepermukaan sebagai terjemahan dari kata education sebagaimana disebutkan diatas.

Pada masa klasik, kita mengenal istilah ta'dib untuk menunjuk kepada pendidikan, seperti tersebut dalam hadits Nabi. Pengertian semacam ini terus terpakai sepanjang masa kejayaan islam itu; hingga semua ilmu Pengetahuan yang dihasilkan oleh akal manusia pada waktu itu disebut adab baik yang yang langsung berhubungan dengan Islam seperti fiqih, tafsir tauhid, ilmu-ilmu bahasa Arab dan lain-lain; maupun yang tidak berhubungan langsung dengan seperti ilmu-ilmu fisika, filsafat, astronomi, kedokteran, farmasi dan lain-lain. Semua buku-buku yang memuat ilmu-ilmu tersebut dinamai kutub al-adab, maka terkenallah al-Adab al-Kabir dan alAdab As-Shagir yang ditulis oleh Ibn AlMuqaffa' (w. 760 M), seorang ahli pendidik yang dimasa itu disebut muaddib.

Muhammad Athiyah al-Abrasyi memberikan pengertian bahwa pendidikan Islam (al-Tarbiyah alIslamiyah) ialah mempersiapkan manusia supaya hidup dengan sempurna dan berbahagia, mencintai tanah air, tegap jasmaninya, sempurna 
budi pekertinya, teratur pikirannya, halus perasaannya, mahir dalam pekerjaannya, manis tutur katanya baik dengan lisan maupun tulisan.

Sedangkan Marimba memberikan pengertian bahwa; Pendidikan Islam adalah bimbingan jasmani dan rohani berdasarkan hukum-hukum agama Islam menuju kepada terbentuknya kepribadian utama menurut ukuranukuran Islam.

\section{Tujuan Pendidikan Islam}

Pendidikan Agama Islam merupakan pendidikan yang berkesadaran dan bertujuan, Allah telah menyusun landasan pendidikan yang jelas bagi seluruh umat manusia melalui Syariat Islam, termasuk tentang tujuan pendidikan agama Islam.

Para ahli mengemukakan pendapatnya tentang tujuan pendidikan agama Islam. Menurut Imam al-Ghazali berpendapat bahwa tujuan Pendidikan Agama Islam adalah membina insan paripurna yang bertaqarrub kepada Allah, bahagia di dunia dan di akhirat. Tidak dapat dilupakan pula bahwa orang yang megikuti pendidikan akan memperoleh kelezatan ilmu yang dipelajarinya dan kelezatan ini pula yang dapat mengantarkannya kepada pembentukan insan paripurna.

Menurut M Athiyah al-Abrasy, mengemukakan bahwa tujuan Pendidikan dan pengajaran adalah sebagai berikut : (a) untuk membantu pembentukan akhlak yang mulia; (b) pendidikan dan pengajaran bukanlah sekedar memenuhi otak anak didik dengan segala macam ilmu yang belum mereka ketahui, tetapi mendidik akhlak dan jiwa mereka, menanamkan rasa fadhilah (keutamaan): (c) membiasakan mereka dengan kesopanan yang tinggi, mempersiapkan mereka untuk suatu kehidupan yang suci seluruhnya, ikhlas, dan jujur; (d) persiapan untuk kehidupan dunia dan akhirat; (e) pendidikan Islam memiliki dua orientasi yang seimbang, yaitu memberi persiapan bagi anak didik untuk dapat menjalani kehidupannya di dunia dan juga kehidupannya di akhirat; (f) persiapan untuk mencari rizki dan pemeliharaan segi-segi kemanfaatan; (g) pendidikan Agama Islam tidak bersifat spiritual, ia juga memperhatikan kemanfaatan duniawi yang dapat diambil oleh siswa dari pendidikannya; (h) menumbuhkan roh ilmiah (scientific spirit ) pada pelajar dan memuaskan keinginan hati untuk mengetahui (curiosity) dan memungkinkan ia mengkaji ilmu sebagai sekedar ilmu. Dengan demikan, Pendidikan Agama Islam tidak hanya memperhatikan pendidikan agama dan akhlak, tapi juga memupuk perhatian kepada sains, sastra, seni, dan lain sebagainya, meskipun tanpa unsurunsur keagamaan didalamnya; dan (i) menyiapkan pelajar dari segi profesinal, tekhnis, dan dunia kerja supaya ia dapat menguasai profesi tertentu.

Menurut Ahmad D. Marimba mengemukakan dua macam tujuan, yaitu tujuan sementara dan tujuan akhir. Tujuan sementara yaitu sasaran sementara yang harus dicapai oleh umat Islam yang melaksanakan pendidikan Islam. Tujuan sementara artinya tercapainya berbagai kemampuan seperti kecakapan jasmaniah, pengetahuan membaca, menulis, dan ilmu-ilmu lainnya. Sedangkan tujuan akhir yaitu terwujudnya kepribadian muslim yang mencakup aspek-aspeknya untuk merealisasikan atau menceminkan ajaran agama Islam.

Menurut Zakiah Darajat membagi tujuan Pendidikan Agama Islam menjadi 4 (empat) macam, yaitu: (1) Tujuan umum. Tujuan umum adalah tujuan yang akan dicapai dengan semua 
kegiatan pendidikan, baik dengan pengajaran atau dengan cara lain; (2) Tujuan akhir. Tujuan akhir adalah tercapainya wujud kamil, yaitu orang yang telah mencapai ketakwaan dan menghadap Allah dalam ketakwaannya; (3) Tujuan sementara. Tujuan sementara adalah tujuan yang akan dicapai setelah anak diberi sejumlah pengalaman tertentu yang direncanakan dalam suatu kurikulum pendidikan formal; dan (4) Tujuan operasional. Tujuan operasional adalah tujuan praktis yang akan dicapai dengan sejumlah kegiatan pendidikan tertentu.

Tujuan Pendidikan Agama Islam yang merupakan sebuah Rumusan dari Kongres Pendidikan Islam se Dunia di Islamabad tahun 1980 dan hasil keputusan seminar Pendidikan Islam se Indonesia taggal 07 sampai 11 Mei 1960 di Cipayung Bogor menghasilkan: (a) Rumusan yang di tetapkan dalam kongres se Dunia tentang Pendidikan Islam sebagai berikut : "Education should aim at the balanced growth of total personality of man through the training of man's spirit, intellect the rational self, feeling and bodily sense. Education should there for cater for the growth of man in all its aspect, spiritual, intellectual, imaginative, physical, scientific, linguistic, both individually and collectively, and motivate, all these aspect toward goodness and attainment perfection. The ultimate aim of education lies in the realization of complete submission to Allah on the level of individual. The community and humanity at larga"; dan (b) Rumusan hasil keputusan seminar pendidikan Islam se Indonesia tanggal 07 sampai dengan 11 mei 1960 di Cipayung, BogoraDari uraian diatas dapatlah di simpulkan bahwa pendidikan Islam mempunyai tujuan yang luas dan dalam, seluas dan sedalam kebutuhan hidup manusia sebagai makhluk individu dan sebagai makhluk sosial yang menghamba kepada khaliknya dengan dijiwai oleh nilai-nilai ajaran agama.

Oleh karena itu pendidikan Islam bertujuan untuk menumbuhkan pola kepribadian manusia yang bulat melalui latihan kejiwaan kecerdasan otak, penalaran, perasaan dan indera.

Pendidikan ini harus melayani pertumbuhan manusia dalam semua aspek, baik aspek spiritual, intelektual, imajinasi, maupun aspek ilmiah, (secara perorangan maupun secara berkelompok). Dan pendidikan ini mendorong aspek tersebut ke arah keutamaan serta pencapaian kesempurnaan hidup.

Tujuan ini merupakan cerminan dan realisasi dari sikap penyerahan diri sepenuhnya kepada Allah, baik secara perorangan, masyarakat, maupun sebagai umat manusia keseluruhannya. Sebagai hamba Allah yang berserah diri kepada Khaliknya, ia adalah hamba-Nya yang berilmu pengetahuan dan beriman secara bulat, sesuai kehendak penciptaNya untuk merealisikan cita-cita yang terkandung dalam firman Allah SWT, Qs. Al-Anam: 162 Artinya: "Katakanlah, sesungguhnya salatku dan ibadahku dan hidupku serta matiku hanya untuk Allah, Pendidikan sekalian alam."

Tujuan utama dari pendidikan Islam ialah mencapai ridla Allah. Dengan pendidikan diharapkan akan lahir individu-individu yang baik, bermoral, berkualitas sehingga bermanfaat bagi dirinya, keluarganya, masyarakatnya, bangsanya serta umat manusia umumnya. Manusia adalah fokus utama dari pendidikan. Ia terdiri dari jasmani dan rohani. Karenanya institusi pendidikan seharusnya lebih memfokuskan perhatiannya kepada substansi kemanusiaan, membuat system yang mendukung kepada terbentuknya manusia yang baik. Pendidikan diharapkan mampu 
mengantarkan anak didik untuk memiliki kemakmuran materi dan juga individu yang memiliki kebahagiaan dunia dan akherat.

Tujuan pendidikan identik dengan gambaran manusia terbaik menurut orang-orang tertentu. Kualitas hidup seseorang ditentukan oleh pandangan hidupnya. Bila pandangan hidupnya berupa agama, maka manusia yang baik yang menjadi tujuan pendidikan adalah manusia yang baik menurut agamanya, Dalam Al Qur'an Allah SWT berfiman:

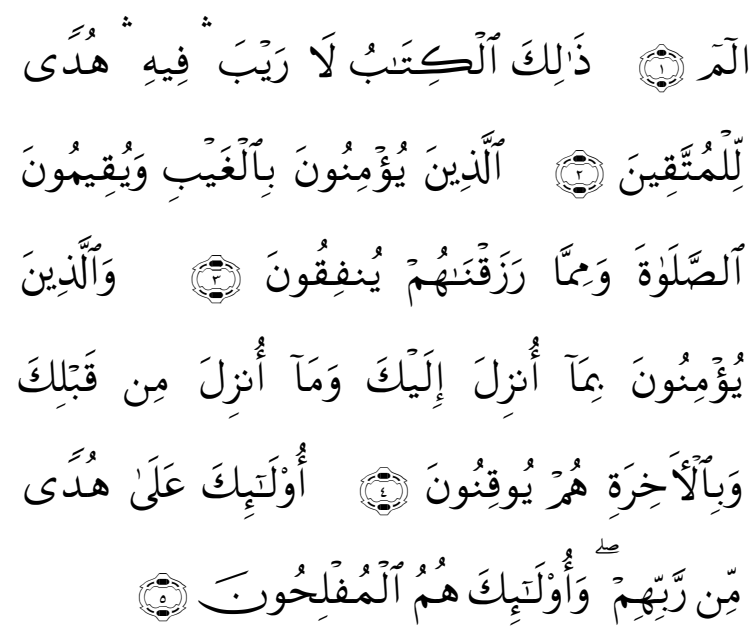

Artinya : "Alif laam miin. Kitab (Al Quran) ini tidak ada keraguan padanya; petunjuk bagi mereka yang bertaqwa. (Yaitu) mereka yang beriman kepada yang ghaib, yang mendirikan shalat, dan menafkahkan sebahagian rezki yang Kami anugerahkan kepada mereka. Dan mereka yang beriman kepada kitab (Al Quran) yang telah diturunkan kepadamu dan Kitab-Kitab yang telah diturunkan sebelummu, serta mereka yakin akan adanya (kehidupan) akhirat. Mereka Itulah yang tetap mendapat petunjuk dari Tuhan mereka, dan merekalah orang-orang yang beruntung." (QS. Al Baqarah, 2: 1-5).

Alif, Lam, miim, ayat yang cukup singkat, tetapi sangat dalam maknanya, hanya Allah yang tahu rahasianya. Sudah cukup lama para ulama al-Qur'an berbeda pendapat. Allahu A'lam, hanya Allah yang mengetahui, itulah jawaban yang dikemukakan oleh para ulama abad pertama hingga abad ketiga. Tampaknya jawaban Allabu A'lam yakni Allah lebih mengetahui masih diangap jawaban yang relevan sampai saat ini, meskipun demikian jawaban itu masih dianggap kurang memuaskan.

Pada ayat ini menggunakan isyarat jauh untuk menunjuk al-Qur'an. Semua ayat yang menunjuk kepada firman-firman Allah dengan nama alQur'an (bukan al-Kitab) yang mengarah pada isyarat dekat "hadzal Qur'an". Penggunaan isyarat jauh ini bertujuan memberi kesan bahwa kitab suci ini berada dalam kedudukan tinggi dan sangat jauh dari jangkauan makhluk, karena ia bersumber dari Allah Yang Maha Tinggi Maha Bijaksana, sedang penggunaan kata "hadza ini" untuk menunjukkan betapa dekat tuntunantuntunannya pada fitrah manusia.

Menurut Al Syaibani, terdapat tiga macam tujuan tahapan pendidikan, yaitu Tujuan tertinggi, tujuan umum dan tujuan khusus. Tujuan tertinggi barangkali tidak akan kunjung tercapai namun harus dijadikan pedoman bagi seluruh tingkat dan proses pendidikan. Tujuan ketiga terlalu rinci, yang hanya ada dalam setiap lembaga pendidikan. Adapun tujuan umum pendidikan biasanya dikaitkan dengan pandangan hidup yang diyakini kebenarannya oleh penyusun tujuan tersebut.

Pendidikan Islam juga memiliki tujuan yang tersendiri sesuai dengan falsafah dan pandangan hidup yang digariskan oleh Al Qur'an. Abdur Rahman Shalih Abdullah menyatakan bahwa tujuan pendidikan dalam islam harus didesain sedemikian rupa sehingga dari setiap tiga komponen manusia, yakni badan ragawi, ruh dan akal mendapat perhatian yang sama dan seimbang. Kegagalan untuk 
memberikan perhatian yang seimbang ini, akan berakibat pada rusaknya tatanan tiga komponen utama tersebut yang pada gilirannya akan mengakibatkan munculnya pribadi yang tidak memenuhi kualifikasi sebagai khalifah.

Ibnu Khaldun menyatakan bahwa tujuan pendidikan islam meliputi tujuan keagaman yang berorientasi amal untuk akhirat dan tujuan ilmiah keduniaan untuk kemanfaatan atau persiapan untuk kehidupan. Sedangkan Al Ghazali berpendapat bahwa tujuan pendidikan islam yang paling utama adalah beribadah dan bertaqarrub kepada Allah SWT, dan kesempurnaan insani yang tujuannya kebahagiaan dunia dan akhirat.

Menurut An Nahlawi, tujuan asasi dari keberadaan manusia di muka bumi ini adalah beribadah dan tunduk kepada Allah SWT, serta menjadi kahlifah di muka bumi dengan memakmurkannya dengan melaksanakan syariat dan mentaati Allah SWT. Selaras dengan tujuan tersebut, maka pendidikan selayaknya memiliki tujuan yang sama pula, yaitu : mengembangkan pikiran manusia dan mengatur tingkah lakunya serta perasaannya berdasarkan Islam. Dengan demikian demikian tujuan akhir pendidikan islam adalah merealisasikan ubudiyyah kepada Allah di dalam kehidupan manusia, baik individu maupun masyarakat. Adapun seluruh tujuan pendidikan yang diagungkan oleh pendidikan barat dewasa ini, sebenarnya telah tercakup dalam tujuan akhir pendidikan islam. Pendidikan Islam telah menjunjung tinggi dan mengarahkan tujuan itu kepada arah yang ideal, sehingga pendidikan itu sendiri terhindar dari penyimpangan atau pun ketergelinciran; mengabdi kemanusiaan serta mewujudkan kebahagiaan individu dan masyarakat.

\section{Prinsip Dasar Pendidikan Islam}

Ramayulis menegaskan bahwa Prinsip Pendidikan diambil dari sumber dasar pendidikan, baik berupa agama ataupun ideologi yang dianut. Adapun dasar pendidikan islam adalah Al Qur'an sebagai sumber Pertama dan Utama dan Sunnah Rasul SAW sebagai sumber kedua. Sementara itu, Al Syaibany memperluas lagi dasar-dasar tersebut mencakup sumber-sumber syariat islam lainnya berupa ijtihad, dan pendapatpendapat yang dapat dipegangi yang keseluruhannya berdasarkan kepada kedua sumber pertama.

Prinsip Pendidikan Islam juga ditegakkan diatas dasar yang sama dan berpangkal dari pandangan Islam secara filosofis terhadap jagad raya, manusia, masyarakat, ilmu pengetahuan dan akhlak. Pandangan Islam terhadap masalah-masalah tersebut digariskan dalam beberapa prinsip. Prinsip-prinsip dasar pendidikan islam tersebut antara lain: Pertama, Implikasi dari Karakteristik Manusia. Manusia adalah fokus utama dalam proses pendidikan. Ajaran Islam mengemukakan empat macam ciri-ciri manusia yang membedakannya dengan makhluk lain yaitu Fitrah; Kesatuan ruh dan Jasad (wahdah al ruh wa al jism); dan kebebasan berkehendak (hurriyatul iradah).

\section{Kesesuaian dengan Fitrah}

Para ahli pendidikan sepakat bahwa teori dalam praktek pendidikan sangat dipengaruhi oleh pandangan tentang fitrah manusia. Praktek-praktek pendidikan dapat mengalami kegagalan bila tidak dibangun di atas konsep yang jelas mengenai fitrah manusia. Fitrah manusia yang dibawa sejak lahir dapat dipengaruhi oleh lingkungan sekitar, berinteraksi dengan faktor-faktor eksternal, mengalami modifikasi dan perkembangan. Pendidikan dalam islam 
diarahkan dalam kerangka memelihara dan menjaga fitrah manusia untuk tetap berada dalam ruang lingkup ajaran islam. Konsep fitrah mengharuskan pendidikan islam bertujuan untuk memperkuat hubungan dengan Allah. Konsep fitrah dalam islam meniscayakan upaya-upaya sistematis untuk mengarahkan manusia dalam mencapai tujuan tersebut

\section{Kesatuan Ruh dan Jasad}

A.K. Modawi, sebagaimana dikutip oleh Abdur Rahman Shalih Abdullah, dalam penegasannya terhadap Al Qur'an sebagai sumber utama pendidikan membuatnya menyerukan kepada pencapaian tujuan pendidikan yang komprehensif yang memperhatikan jiwa, raga dan pikiran manusia.

\section{Kebebasan Berkehendak}

Kebebasan sebagai karakteristik manusia meliputi berbagai dimensi seperti kebebasan beragama, berbuat, mengeluarkan pendapat, memiliki, berfikir, berekspresi dan sebagainya. Namun demikian kebebasan tersebut tidaklah bersifat mutlak dimana manusia boleh berbuat sekehendaknya. Kebebasan dalam islam adalah kebebasan yang terikat oleh rasa tanggung jawab, nilai-nilai agama dan moralitas yang dianut oleh masyarakat, undang-undang yang berlaku, kebersamaan, keadilan dan akal logika, serta tidak menghalangi kebebasan orang lain. Ini berimplikasi pada perlunya memperhatikan faktor peserta didik dalam pencapaian tujuan pendidikan.

Kedua, pendidikan Islam adalah Pendidikan Integral dan terpadu. Pendidikan Islam tidak mengenal adanya pemisahan antara agama dan aspek hidup keduniaan. Demikian pula, islam tidak mengenal pemisahan antara sains dan agama. Karenanya, penyatuan sistem pendidikan islam adalah tuntutan akidah islam. Ini berimplikasi bahwa dalam pendidikan islam tidak dibenarkan adanya dikotomi pendidikan antara pendidikan agama dan sains.

Dalam pemahaman Modawi mengenai universalitas islam, terpantul semangat untuk menerapkan integralitas dan universalitas islam dalam lapangan pendidikan. "Islam harus diapresiasi, tidak hanya sebagai agama personal dan pribadi bangsa Arab, tetapi sebagai suatu ideologi komplit yang mengatur kehidupan masyarakat dunia". Dengan demikian, maka pendidikan Islam pada hakekatnya ialah aktivitas yang lengkap dan menyeluruh yang dilakukan oleh setiap individu dan dalam interaksinya dengan yang lain. Ini berarti bahwa pendidikan itu menyertai seluruh kehidupan manusia. Pendidikan Islam disatu sisi adalah persiapan untuk kehidupan dan pada saat yang bersamaan adalah hidup itu sendiri.

Ketiga, pendidikan Islam adalah Pendidikan Yang Seimbang. Pandangan islam yang menyeluruh terhadap semua aspek kehidupan mewujudkan adanya keseimbangan (tawazun). Prinsip keseimbangan, yang pada hakekatnya me \rupakan ciri alam semesta ini, meliputi keseimbangan antara kehidupan duniawi dan ukhrawi; kesimbangan antara jasad dan ruh; dan keseimbangan antara individu dan masyarakat. Begitu pula keseimbangan antara unsur spiritual dan unsur material, kesimbangan antara dunia nyata dan dunia ghaib.

\section{Metode Pendidikan}

Metode Pendidikan menjadi penting karena kenyataan materi 
pendidikan tiada mungkin dipelajari secara efisien, kecuali disampaikan dengan cara-cara tertentu. Ketiadaan metode pendidikan yang efektif dapat menghambat atau membuang secara sia-sia waktu dan upaya pendidikan. Penggunaan metode pendidikan didasarkan atas tiga pokok, yaitu: (1) Sifat-sifat dan kepentingan yang berkenaan dengan tujuan utama pendidikan islam, yaitu penghambaan manusia mukmin yang mengaku sebagai hamba Allah; (2) Berkenaan dengan metode yang betul-betul yang berlaku yang disebutkan dalam Al Qur'an ataupun disimpulkan daripadanya; dan (3) Membicarakan tentang pergerakan dan disiplin

$$
\text { Dalam pendidikan yang }
$$

diterapkan di Barat, metode-metode pendidikan hampir sepenuhnya tergantung kepada kepentingan para murid, para guru hanya bertindak sebagai motivator. Sistem yang cenderung dan mengarah kepada anak didik sebagai pusat (child centre) ini sangat menghargai adanya para individu siswa. Akibatnya, pembentukan karakter hampir kurang menjadi perhatian guru.

Pada titik ini sudah terdapat perbedaan besar antara metode pendidikan Islam dengan metode pendidikan Barat yang dianggap sebagai metode pendidikan modern itu. Metode pendidikan islam di samping sangat menghargai kebebasan individu anak didik, guru juga bertanggung jawab dalam membentuk karakter muridnya.

Dalam pandangan An Nahlawi, metode-metode pendidikan yang paling penting dan menonjol yang dapat ditemukan dalam Al Qur'an dan Sunnah Nabi SAW ialah: (1) Metode hiwar (percakapan) Qur'ani dan Nabawi; (2) Mendidik dengan kisah-kisah Qur'ani dan Nabawi; (3) Mendidik dengan amtsal (perumpamaan) Qur'ani dan
Nabawi; (4) Mendidik dengan memberi teladan; (5) Mendidik dengan pembiasaan diri dan pengamalan; (6) Mendidik dengan mengambil 'ibrah (pelajaran) dan mau'izhah (peringatan); dan (7) Mendidik dengan targhib (membuat senang) dan tarhib (membuat takut).

Sedangkan menurut Abdullah (1991), metode verbal yang muncul dalam Al-Qur'an diantaranya menyampaikan cerita, memberikan metafora, menyodorkan pertanyaan dan menggunakan pendekatan deduksi. Metode lain, yang juga disebut oleh $\mathrm{Al}$ Qur'an adalah perjalanan ilmiah.

Sementara itu, Al Syaibany menyebutkan beberapa metode yang paling menonjol dari yang telah digunakan oleh para pendidik muslim, yakni : Metode Pengambilan Keputusan (Induktif), Metode Perbandingan (Qiyasiah), Metode Kuliah, Metode Dialog dan Perbincangan, Metode Lingkaran (Halaqah), Metode Riwayat, Metode Mendenganr, Metode Membaca, Metode Imla' (Dictation), Metode Hafalan, Metode Pemahaman, dan Metode Lawatan untuk Menuntut Ilmu.

\section{Pendidikan Islam dan Pembentukan Kepribadian Muslim}

Dalam Islam, keseluruhan proses dalam pendidikan ditujukan untuk memunculkan kepribadian yang diwarnai oleh ajaran islam. Pendidikan dalam islam tidaklah semata-mata berorientasi pada pemenuhan kebutuhan fikri, akan tetapi diarahkan pada penumbuhan aspek tingkah laku yang pada akhirnya menjadi kepribadian yang mapan yang sesuai dengan nilai-nilai islami.

Dalam hubungan antara tujuan pendidikan dan pembentukan kepribadian, Hasan Langgulung, menyebutkan bahwa tujuan-tujuan yang 
ingin dicapai oleh pendidikan dapat diringkaskan dalam dua tujuan pokok: pembentukan insan yang saleh dan beriman kepada Allah dan agama Nya; dan pembentukan masyarakat yang saleh yang mengikuti petunjuk agama islam dalam segala urusannya.

Kedua tujuan pokok pendidikan islam tersebut, bermuara pada pembentukan kepribadian muslim sebagai individu dan sebagai suatu ummah. Keduanya terintegrasi dalam bentuk suatu pola yang sama.

\section{Pengertian Kepribadian}

Kepribadian biasanya menyangkut banyak aspek seperti kedirian, karakter, watak, ego, oknum, self dan bahkan yang menyangkut identitas bangsa. para ahli, meskipun berbeda pendapat dalam merumuskan batsan dan pengertian kepribadian, pada umumnya sepakat dan menyatu dalam titik temu yang mengandung pengertian umum dari kepribadian, yaitu keseluruhan tingkah laku yang tampak dalam ciri khas seseorang.

Adapun kepribadian muslim, sebagaimana digambarkan oleh Fadhil Al Djamaly, digambarkan sebagai muslim yang berbudaya, yang hidup bersama Allah dalam tingkah laku sepanjang perjalanan kehidupannya. Kepribadian muslim mempunyai hubungan yang erat dalam suatu lingkaran hubungan yang meliputi Allah, Alam semesta, dan Manusia. Dengan kepribadian muslim, manusia mengembangkan dirinya dengan bimbingan petunjuk ilahi, dalam rangka mengemban tugasnya selaku khalifah di muka bumi, dan selalu melaksanakan kewajiban sebagai hamba Allah serta melakukan kepada Nya.

Kepribadian Muslim juga dapat dilihat dari kepribadian orang per orang (individu) dan kepribadian dalam kelompok masyarakat (ummah). Kepribadian individu meliputi ciri khas seseorang dalam sikap dan tingkahlaku, serta kemampuan intelaktual yang dimilikinya. Karena adanya unsur kepribadian yang dimiliki masingmasing, maka sebagai individu seorang Muslim akan menampilkan ciri khasnya masing-masing.

Dengan demikian akan ada perbedaan kepribadian antara seseorang muslim dengan muslim lainnya. Secara fitrah perbedaan ini memang diakui adanya. Islam memandang setiap manusia memiliki potensi yang berbeda, hingga kepada setiap orang dituntut untuk menunaikan perintah agamanya sesuai dengan tingkat kemampuan masing-masing (QS.6:152).

Kalaulah individu merupakan unsur terkecil dari suatu masyarakat, maka tentunya dalam pembentukan kepribadian Muslim sebagai umat akan sulit dipenuhi. Beranjak dari pernyataan tersebut, maka dalam upaya membentuk kepribadian Muslim baik secara individu, maupun sebagai suatu ummah, adanya perbedaan tersebut bagaimana pun tak mungkin dapat diletakkan. Dalam kenyataannya memang dijumpai adanya unsur keberagaman (heterogenitas) dan homogenitas(kesamaan).

Maka walaupun sebagai individu masing-masing kepribadian itu berbeda, tapi dalam pembentukan kepribadian muslim sebagai ummah, perbedaan itu perlu dipadukan. Sumber yang menjadi dasr dan tujuannya adalah ajaran wahyu.

Dasar pembentukan adalah AlQur'an dan hadist, sedangkan tujuan yang akan dicapai menjadi pengabdi Allah yng setia (QS.51:56), sebagai Tuhan yang wajib disembah. Sedangkan pengabdian yang dimaksud didasarkan atas tuntutan untuk menyembah kepada 
Tuhan yang satu : itulah dia Allah Tuhan kamu, tidak ada yang berhak disembah selain dia. Pencipta segala sesuatu, maka sembahlah dia(QS.6:102).

Pernyataan wahyu ini merupakan kerangka acuan dalam pembentukan kepribadian Muslim sebagai ummah. Acuan ini berisi pernyataan, bahwa sitiap Muslim wajib menunjukkan ketundukan yang optimal kepada zat yang menjadi sesembahannya. Dengan demikian secara keseluruhan kaum muslimin mengacu kepada pembentukan sikap kepatuhan yang sama imbasnya diharapkan akan terbentuk sifat dan sikap yang secara umum adalah sama. Inilah yang dimaksud dengan kepribadian muslim sebagai ummah.

Secara individu kepribadian Muslim mencerminkan cirri khas yang berbeda. Ciri khas tersebut diperolah berdasarkan potensi bawaan. Dengan demikian secara potensi (pembawaan) akan dijumpai adnya perbedaan kepribadian antara seorang muslim dengan muslim lainnya. Namun perbedaan itu terbatas pada seluruh potensi yang mereka miliki, berdasarkan factor pembawaan masingmasing meliputi aspek jasmani dan rohani. Pada aspek jasmani seperti perbedaan bentuk fisik, warna kulit, dan cirri-ciri fisik lainnya. Sedangkan pada aspek rohaniah seperti sikap mental, bakat, tingkat kecerdasan, maupun sikap emosi.

Sebaliknya dari aspek roh, ciri-ciri itu menyatu dalam kesatuan fitrah untuk mengabdi kepada penciptannya. Latar belakang penciptaan manusia menunjukkan bahwa secara fitrah manusia memiliki roh sebagai bahan baku yang sama. Menurut Hasan Langgulung, pernyataan tersebut mengandung makna antara lain, bahwa Tuhan memberikan manusia beberapa potensi yang sejalan dengan sifat- sifatnya. Kepibadian secara utuh hanya mungkin dibentuk melalui pengaruh lingkungan, khususnya pendidikan. Adapun sasaran yang dituju dalam pembentukan kepribadian ini adalah kepribadian yang dimiliki akhlak yang mulia. Tingkat kemuliaan akhlak erat kaitannya dengan tingkat keimanan. Sebab Nabi mengemukakan "Orang mukmin yang paling sempurna imannya, adalah orang mukmin yang paling baik akhlaknya."

Disini terlihat ada dua sisi penting dalam pembentukan kepribadian muslim, yaitu iman dan akhlak. Bila iman dianggap sebagai konsep batin, maka batin adalah implikasi dari konsep itu yang tampilanya tercermin dalam sikap perilaku sehari-hari. Keimanan merupakan sisi abstrak dari kepatuhan kepada hukum-hukum Tuhan yang ditampilkan dalam lakon akhlak mulia.

Menurut Abdullah al-Darraz, pendidikan akhlak dalam pembentukan kepribadian muslim berfungsi sebagai pengisi nilai-nilai keislaman. Dengan adanya cermin dari nilai yang dimaksud dalam sikap dan perilaku seseorang maka tampillah kepribadiannya sebagai muslim. Muhammad Darraz menilai materi akhlak merupakan bagian dari nilai-nilai yang harus dipelajari dan dilaksanakan, hingga terbentuk kecendrungan sikap yang menjadi ciri kepribadian Muslim.

Usaha yang dimaksud menurut AlDarraz dapat dilakukan melalui cara memberi materi pendidikan akhlak berupa: (a) Pensucian jiwa; (b) Kejujuran dan benar; (c) Menguasai hawa nafsu; (d) Sifat lemah lembut dan rendah hati; (e) Berhati-hati dalam mengambil keputusan; (f) Menjauhi buruk sangka; (g) Mantap dan sabar; (h) Menjadi teladan yang baik; (i) Beramal saleh dan berlomba-lomba berbuat baik; (j) Menjaga diri (iffah); (k) Ikhlas; (l) Hidup sederhana; dan Pintar 
mendengar dan kemudian mengikutinya (yang baik).

Pembentukan kepribadian muslim pada dasarnya merupakan upaya untuk mengubah sikap kearah kecendrungan pada nilai-nilai keislaman. Perubahan sikap, tentunya tidak terjadi secara spontan. Semua berlajan dalam sautu proses yang panjang dan berkesinambungan. Diantara proses tersebut digambarkan oleh danya hubungan dengan obyek, wawasan, peristiwa atau ide(attitude have referent), dan perubahan sikap harus dipelajari (attitude are learned), menurut Al-Ashqar. Ada hubungan timbale balik antara individu dengan lingkungannya.

Selanjutnya kata Al-Ashqar, jika secara konsekwen tuntutan akhlak seperti yang dipedomankan pada AlQur'an dapat direalisasikan dalam kehidupan sehar-hari, maka akan terlihat ciri-cirinya. Ia memberikan rincian ciri-ciri yang dimaksud sebagai berikut: (a) Selalu menepuh jalan hidup yang didasarkan didikan ketuhanan dengan melaksanakan ibadah dalam arti luas; (b) Senantiasa berpedoman kepada petunjuk Allah untuk memperolah bashirah (pemahaman batin) dan furqan (kemampuan membedakan yang baik dan yang buruk); (c) Mereka memperoleh kekuatan untuk menyerukan dan berbuat benar, dan selalu menyampaikan kebenaran kepada orang lain; (d) Memiliki keteguhan hati untuk berpegang kepada agamanya; (f) Memiliki kemampuan yang kuat dan tegas dalam menghadapi kebatilan; (g) Tetap tabah dalam kebenaran dalam segala kondisi; (h) Memiliki kelapangan dan ketentraman hati serta kepuasan batin hingga sabar menerima cobaan; (i) Mengetahui tujuan hidup dan menjadikan akhirat sebagai tujuan akhir yang lebih baik; dan (j) Kembali kepada kebenaran dengan melakukan tobat dari segala kesalahan yang pernah dibuat sebelumnya.

Dalam hal ini Islam juga mengajarkan bahwa factor genetika (keturunan) ikut berfungsi dalam pembentukan kepribadian Muslim. Oleh karena itu, filsafat pendidikan Islam memberikan pedoman dalam pendidikan Prenatal (sebelum lahir), Pembuahan suami atau istri sebaiknya memperhatikan latar belakang keturunan masing-masing pilihan (tempat yang sesuai) karena keturunan akan membekas (akhlak bapak akan menurun pada anak).

Kemudian dalam proses berikutnya, secara bertahap sejalan dengan tahapperkembangan usianya, pedoman mengenai pendidikan anak juga telah digariskan oleh filsafat pendidikan Islam. Kalimat tauhid mulai diperdengarkan azan ketelingan anak yang baru lahir. Kenyataan menunjukkan dari hasil penelitian ilmu jiwa bahwa bayi sudah dapat menerima rangsangan bunyi semasa masih dalam kandungan. Atas dasar kepentingan itu, maka menggemakan azan ketelingan bayi, pada hakikatnya bertujuan memperdengarkan kalimat tauhid diawak kehidupannya didalam dunia.

Pada usia selanjutnya, yaitu usia tujuh tahun anak-anak dibiasakan mengerjakan shalat, dan perintah itu mulai diintensifkan menjelang usia sepuluh tahun. Pendidikan akhlak dalam pembentukan pembiasaan kepada halhal yang baik dan terpuji dimulai sejak dini. Pendidikan usia dini akan cepat tertanam pada diri anak. Tuntunan yang telah diberikan berdasarkan nilai-nilai keislaman ditujukkan untuk membina kepribadian akan menjadi muslim. Dengan adanya latihan dan pembiasaan sejak masa bayi, diharapkan agar anak dapat menyesuaikan sikap hidup dengan kondisi yang bakal mereka 
hadapi kelak. Kemampuan untuk menyesuikan diri dengan lingkungan tanpa harus mengorbankan diri yang memiliki ciri khas sebagai Muslim, setidaknya merupakan hal yang berat.

Dengan demikian pembentukan kepribadian muslim pada dasarnya merupakan suatu pembentukan kebiasaan yang baik dan serasi dengan nilai-nilai akhlak al-karimah. Untuk itu setiap Muslim diajurkan untuk belajar seumur hidup, sejak lahir (dibesarkan dengan yang baik) hingga diakhir hayat. Pembentukan kepribadian Muslim secara menyeluruh adalah pembentukan yang meliputi berbagai aspek, yaitu: (a) Aspek idiil (dasar), dari landasan pemikiran yang bersumber dari ajaran wahyu; (b) Aspek materiil (bahan), berupa pedoman dan materi ajaran yang terangkum dalam materi bagi pembentukan akhlak al-karimah; (c) Aspek sosial, menitik beratkan pada hubungan yang baik antara sesama makhluk, khususnya sesama manusia; (d) Aspek teologi, pembentukan kepribadian muslim ditujukan pada pembentukan nilai-nilai tauhid sebagai upaya untuk menjadikan kemampuan diri sebagai pengabdi Allah yang setia; (e) Aspek teologis (tujuan), pembentukan kepribadian Muslim mempunyai tujuan yang jelas; (f) Aspek duratife (waktu), pembentukan kepribadian Muslim dilakukan sejak lahir hingga meninggal dunia; (g) Aspek dimensional, pembentukan kepribadian Muslim yang didasarkan atas penghargaan terhadap factor-faktor bawaan yang berbeda (perbedaan individu); dan (h) Aspek fitrah manusia, yaitu pembentukan kepribadian Muslim meliputi bimbingan terhadap peningkatan dan pengembangan kemampuan jasmani, rohani dan ruh.

Pembentukan kepribadian muslim merupakan pembentukan kepribadian yang utuh, menyeluruh, terarah dan berimbang. Konsep ini cenderung dijadikan alasan untuk memberi peluang bagi tuduhan bahwa filsafat pendidikan Islam bersifat apologis (memihak dan membenarkan diri). Penyebabnya antara lain adalah ruang lingkupnya terlalu luas, tujuan yang akan dicapai terlampau jauh, hingga dinilai sulit untuk diterapakan dalam suatu sistem pendidikan.

Berangkat dari teori kepribadian muslim diatas, maka kita dapat membagi kepribadian muslim tersebut kepada dua bagian, yaitu kepribadian kemanusian (basyariyah) yang meliputi ciri khas seseorang dalam bentuk sikap dan tingkah laku maupun intelektual; dan kepribadian samawi (kewahyuan) berupa corak kepribadian yang dibentuk melalui petunjuk wahyu.

\section{Proses Pembentukan Kepribadian Islam}

Ciri khas kepribadian muslim adalah terwujudnya prilaku mulia sesuai dengan tuntunan Allah SWT, yang dalam istilah lain disebut akhlak yang mulia. Misi kerasulan yang berorientasi pada pembentukan akhlak yang mulia, menggambarkan hubungan yang erat antara keimanan seseorang dan ketinggian akhlaknya. Akhlak yang mulia mengandung konotasi pengaturan hubungan yang baik antar hamba dengan Allah, dengan sesamanya, dan dengan makhluk lainnya. Dalam hal ini, pendidikan akhlak berfungsi sebagai pemberi nilai-nilai islam. Dengan adanya nilai-nilai islam itu dalam diri seseorang atau ummah, akan terbentuk pulalah kepribadiannya sebagai kepribadian muslim 
Pembentukan Kepribadian secara Perorangan

Pembentukan kepribadian Muslim sebagai individu, adalah pembentukan kepribadian yang diarahkan kepada peningkatan dan pengembangan factor dasar (bawaan) dan factor ajar (lingkungan), dengan berpedoman kepada nilai-nilai keislaman. factor dasar pengembangan dan ditingkatkan kemampuannya melalui bimbingan dan pembiasaan berfikir, bersikap dan bertingkah laku menurut norma-norma Islam. Sedangkan factor ajar dilakukan dengan cara mempengaruhi individu melalui proses dan usaha membentuk kondisi yang mencerminkan pola kehidupan yang sejalan dengan normanorma Islam seperti contoh, teladan, nasihat, anjuran, ganjaran, pembiasaan, hukuman, dan pembentukan lingkungan serasi.

Proses ini diarahkan pada terciptanya insan yang saleh, yang dimaksudkan sebagai manusia yang mendekati kesempurnaan. Secara perorangan, proses pembentukan kepribadian dapat dilakukan dalam tiga macam pendidikan, yaitu: (1) Pra natal education. Proses pendidikan jenis ini dilakukan secara tidak langsung, dimulai pada saat pemilihan calon suami atau isteri, kemudian dilanjutkan dengan sikap dan prilaku orang tua yang islami disaat bayi sedang dalam kandungan, pemberian makanan yang halal dan baik, serta dilengkapi dengan sikap penerimaan yang dari kedua orang tua atas kehadiran bayi tersebut; (2) Pendidikan secara langsung oleh Pihak lain. Proses pendidikan jenis ini dilakukan secara langsung oleh orang lain (orang tua di keluarga, guru di sekolah, pemimpin/tokoh di dalam masyarakat dan para ulama). Sepanjang kehidupan manusia diperlukan keterlibatan orang lain untuk mendidik manusia supaya dia mengetahui tentang dirinya dan lingkungannya. Sekaligus bantuan orang lain agar ia dapat melakukan kegiatan proses pendidikan secara pribadi (self education/tarbiyah dzatiyah); dan (3) Self education (Pendidikan mandiri). Proses ini dilaksanakan melalui kegiatan pribadi tanpa bantuan orang lain seperti membaca buku-buku, melalui penelitian dan penghayatan untuk menemukan segala sesuatu tanpa bantuan orang lain.

\section{Pembentukan Kepribadian secara Ummah}

Proses ini diarahkan pada terbentuknya masyarakat yang saleh, yaitu masyarakat yang percaya bahwa ia mempunyai risalah untuk ummat manusia, yaitu risalah keadilan, kebenaran dan kebaikan. Proses pembentukan kepribadian muslim secara ummah dilakukan dengan memantapkan kepribadian individu (karena individu juga bagian dari ummah). Juga dapat dilakukan dengan menyiapkan kondisi dan tradisi yang memungkinkan terbentuknya kepribadian ummah.

Pembentukan kepribadian muslim sebagai ummah dapat berjalan seiring dengan pembentukan kepribadian muslim sebagai pribadi. Ketimpangan pada salah satu diantara kedua proses tersebut dapat mengakibatkan rusaknya proses pendidikan yang lainnya. Untuk itu, ummah ataupun masyarakat seperti dalam pandangan Quthb, disamping menjadi tujuan akhir dari pendidikan islam sekaligus merupakan alat dan sarana untuk mengokohkan ajaranajaran islam dan membentuk orangorang yang melaksanakannya.

Komunitas Muslim (kelompok seakidah) ini disebut ummah. Individu merupakan unsur dalam kehidupan masyarakat. Maka dengan membentuk kesatuan pandangan hidup pada setiap 
individu, rumah tangga, diharapkan akan ikut mempengaruhi sikap dan pandangan hidup dalam masyrakat, bangsa, dan ummah. Adapun pedoman untuk mewujudkan pembentukan hubungan itu secara garis besarnya terdiri atas tiga macam usaha, yakni : (1) memberi motivasi untuk berbuat baik, (2) mencegah kemungkaran dan, (3) beriman kepada Allah. Untuk memenuhi tiga persyaratan itu, maka usaha pembentukan kepribadian Muslim sebagai ummah dilakukan secara bertahap, sesuai dengan ruang lingkup dan kawasan yang menjadi lingkungan masing-masing.

Abdullah al-Daraz membagi kegiatan pembentukan itu menjadi empat tahap meliputi: Pertama, Pembentukan nilai-nilai Islam dalam keluarga. Bentuk penerapannya adalah dengan Cara melaksanakan pendidikan akhlak dilingkungan keluarga. Langkah yang ditempuh adalah: (a) Memberikan bimbingan untuk berbuat baik kepda kedua orang tua; (b) Memelihara anak dengan kasih sayang; (c) Memberi tuntunan anak akhlak kepada anggota keluarga; (d) Membiasakan untuk mengahargai peraturan-peraturan dalam rumah; dan (e) Membiasakan untuk memenuhi kewajiban sesame kerabat seperti ketentuan soal waris.

Pembentukan nilai-nilai Islam dalam keluarga dinilai penting. Pertama, keluarga paling berpotensi untuk membentuk nilai - nilai dasar, karena lingkungan sosial pertama kali yang dikenal anak. Kedua, Keluraga menempati peran penting dalam pembentukan masyarakat. Keluarga senagai organisasi sosial yang paling kecil, tapi mempengaruhi masa depan suatu masyarakat.

Kedua, Pembentukan nilai-nilai dalam hubungan sosial. Kegiatan hubungan sosial mencakup upaya penerapan nilai-nilai akhlak dalam pergaulan sosial langkah-langkah pelaksanaanya mencakup: (a) Melatih diri untuk tidak melakukan perbuatan keji dan tercela; (b) Mempererat hubungan kerjasama dengan cara menghindarkan diri dari perbuatan yang dapat mengarah kepada rusaknya hubungan sosial; (c) enggalakkan perbuatan-perbuatan yang terpuji dan memberi manfaat dala kehidupan bermasyarakat seperti memaafkan kasalahan, menepati janji, memperbaiki hubungan antar manusia, dan amanah; dan (d) Membina hubungan menurut tata tertib, seperti berlaku sopan, meminta izin ketika masuk rumah, berkata baik, serta memberi dan membalas Salam.

Ketiga, Membentuk nilai-nilai Islam dalam kehidupan berbangsa. Adapun upaya untuk membentuk nilainilai Islam dalam konteks ini adalah: (a) Kepala negara menerapkan prinsip musyawarah, adil, jujur, dan tanggung jawab; dan (b) Masyarakat Muslim berkewajiban mentaati peraturan, menghindarkan dari perbuatan yang merugikan keharmonisan hidup berbangsa.

Keempat, Pembentukan Nilai-nilai Islam dalam Hubungannya dengan Tuhan. Baik secara individu atau secara ummah, kaum muslimin diharuskan untuk senantiasa menjaga hubungan yang baik dengan Allah SWT. Nilai-nilai Islam yang diterapkan dalam membina hubungan itu mencakup: (a) Senantiasa beriman kepada Allah; (b) Bertaqwa kepada-Nya; (c) Menyatakan syukur atas segala nikmat Allah dan tidak berputus asa dalam mengaharapkan rahmat-Nya; (d) Berdo'a kepada Allah, mensucikan diri, mengagungkan-Nya serta senantiasa mengingat-Nya; dan (e) Menggantungkan niat atas segala perubahan kepada-Nya.

Realisasi dari pembinaan hubungan yang baik kepada Allah ini 
adalah cinta kepada Allah. Puncaknya adalah menempatkan rasa cinta kepadaNya dan kepada Rasul-Nya. Dengan menerapkan kecintaan kepada Allah dan Rasul-Nya diatas segalanya, diharapkan kepribadian Muslim sebagai individu maupun sebagai ummah akan membuahkan sikap untuk lebih mendahulukan kepentingan melaksanakan perintah khalikNya dari kepentingan lain.

Pembentukan kepibadian Muslim sebagai individu, keluarga, masyarakat, maupun ummah pada hakikatnya berjalan seiring dan menuju ketujuan yang sama. Tujuan utamanya adalah guna merealisasikan diri, baik secara pribadi (individu) maupun secara komunitas (ummah) untuk menjadi pengabdi Allah yang setia. Pada tingkat ini terlihat bahwa filsafat pendidikan Islam memiliki sifat yang mendasar (sejalan dengan fitrah), universal (umum) dan terarah pada tujuan yang didasarkan atas konsep yang jelas dan benar adanya.

\section{SIMPULAN}

Pendidikan pada hakekatnya adalah sebuah proses yang bertujuan agar apa yang dilaksanakan dapat menghasilkan pola-pola kepribadian yang baik, membentengi dari krisis moral/akhlak dan menjauhkan dari segala yang merusak tatanan kehidupan. sebab setiap masyarakat memiliki karakteristik, perspektif dan citra trersendiri tentang individu ideal dan dalam menanamkan pola-pola prilaku yang dipengaruhi oleh falsafah dan pandangannya tentang pendidikan. Peran pendidikan islam adalah mengarahkan keseluruhan proses pendidikan tersebut untuk mencapai terwujudnya kepribadian muslim, baik dalam secara pribadi maupun secara umum.

\section{DAFTAR RUJUKAN}

Abdullah, Abdur Rahman Shalih. 1991. Landasan dan Tujuan Pendidikan Menurut Al Qur'an serta Implikasinya. terjemahan HMD Dahlan. Bandung: Diponegoro.

Al 'Affandi, Muhammad. 1996. Esensi Pendidikan Islam dalam Lektur IV.

Al Attas, Syed Muhammad Naquib. 1994. Konsep Pendidikan dalam Islam. Terjemahan Haidar Bagir. Bandung: Mizan.

Al Syaibany, Omar Mohammad al Toumy. 1999. Falsafah Pendidikan Islam. Terjemahan Hasan Langgulung. Jakarta: Bulan Bintang .

An Nahlawi, Abdurrahman. 1979. Ushul at Tarbiyyah al Islamiyyah wa Asaalibuhaa, Dar al Fikr.

Muzayyin Arifin, M. 2008. Kapita Selekta Pendidikan Islam. Jakarta: Bumi Aksara.

Agustin, Ari Ginanjar. 2002. ESQ Emotional Spiritual Quotient. Jakarta: Arga.

Arifin. Muzayyin. 2008. Kapita Selekta Pendidikan Islam. Jakarta: Bumi Aksara.

Faisal, Yusuf Amir. 1995. Reorientasi Pendidikan Islam. Jakarta: Gema Insani Press.

Gordon Dryden \& Jeannette Vos. 2000. Revolusi Cara Belajar I. Bandung: Kaifa.

Husain, Syed Sajjad dan Ashraf, Syed Ali. 1994. Menyongsong Keruntuhan Pendidikan Islam. Terjemahan Rahmani Astuti. Gema Risalah Press.

Langgulung, Hasan. 1985. Pendidikan dan Peradaban Islam. Jakarta Pustaka Al Husna.

Langgulung, Hasan. 1988. Pendidikan Islam Menghadapi Abad ke 21. Jakarta: Pustaka Al Husna. 
Langgulung, Hasan. 1984. Manusia dan Pendidikan. Jakarta: Pustaka Al Husna.

Muzayyin Arifin. 2008. Kapita Selekta Pendidikan Islam. Jakarta: Bumi Aksara.

Quthb, Muhammad. 1984. Sistem Pendidikan Islam. Terjemahan Salman Harun. Bandung: Al Ma'arif.

Ramayulis. 1998. Ilmu Pendidikan Islam. Jakarta: Kalam Mulia.
Ridho, Abu. 1994. Urgensi Tarbiyah Islamiyah. Jakarta: Inqilab Press.

Sulaiman, Fathiyyah Hasan. 1991. Ibnu Khaldun tentang Pendidikan. Terjemahan Azra'ie Zakaria. Jakarta: Minaret.

Ulwan, Abdullah Nashih. 1993. Pendidikan Anak dalam Islam. Terjemahan Saefullah Kamalie. Asy Syiffa Semarang. 